\title{
PEMBENTUKAN SIKAP MANDIRI DAN TANGGUNG JAWAB MELALUI PENERAPAN METODE SOSIODRAMA DALAM PEMBELAJARAN PENDIDIKAN KEWARGANEGARAAN
}

\author{
Premita Sari Octa Elviana \\ SMA Negeri 2 Kediri $^{1}$ \\ Email: mitaocta11@yahoo.com ${ }^{1}$;
}

Naskah diterima: 07/09/2017 revisi: 26/10/2017 disetujui: 29/10/2017

\begin{abstract}
Abstrak
Pendidikan Kewarganegaraan merupakan mata pelajaran yang mengikuti perkembangan zaman.Pendidikan Kewarganegaraan memuat materi tentang isu-isu global, seperti identitas, ketergantungan, moralitas, budaya, etnis, agama, hak, dan tanggung jawab. Isu-isu global tersebut merupakan masalah kewarganegaraan global yang terjadi tidak hanya di negara Indonesia, tetapi juga di negara-negara lain. Tanggung jawab dan mandiri penting untuk dikembangkan pada generasi muda sehingga dapat mengikuti perkembangan zaman. Jika sikap mandiri dalam mengerjakan tugas ada pada diri pribadi maka generasi muda akan memiliki tanggung jawab pula dalam penyelesaian tugas yang diberikan. Kedua karakter tersebut dapat dikembangkan dalam pembelajaran Pendidikan Kewarganegaraan. Sikap mandiri dan tanggung jawab dapat dibentuk melalui metode pembelajaran yang menekankan pada peran aktif peserta didik, membutuhkan kerja individu dan kelompok, dan membutuhkan pemecahan masalah. Metode yang dimaksud adalah metode pembelajaran sosiodrama. Makalah ini akan mendiskripsikan pentingnya sikap mandiri dantanggung jawab serta pembentukan sikap mandiridan tanggung jawabmelalui penerapan metode sosiodrama.
\end{abstract}

Kata kunci: Pendidikan Kewarganegaraan, Mandiri, Tanggung Jawab, Sosiodrama

\section{INDEPENDENCE AND RESPONSIBILITY ATTITUDE FORMATION WITH SOCIODRAMA METHOD IN CIVIC EDUCATION}

\begin{abstract}
Citizenship Education is a subject that follows the times. Citizenship Education contains on global issues, such as identity, dependency, morality, culture, ethnicity, religion, rights, and responsibilities. These global issues are a matter of global citizenship that occurs not only in the country of Indonesia, but also in other countries. Responsibility and independence is important to be developed in the young generation so as to keep up with the times. If selfreliance is personal to the task, the young generation will also be responsible for the completion of the assigned task. Both characters can be developed in Civic Education learning. Independenceand responsibility attitudes can be established through instructional methods that emphasize the active role of learners, require individual and group work, and require problem solving. The method is sociodrama. This paper will describe the importance of independence and responsibility attitudesand the establishment of independence and responsibility attitudes through the application of sociodrama methods
\end{abstract}

Keywords: Citizenship Education, Independence, Responsibility, Sociodrama 


\section{PENDAHULUAN}

Pendidikan merupakan komponen penting dalam keberhasilan pembangunan suatu negara, termasuk Negara Indonesia. Melalui pendidikan akan tercipta sumber daya manusia yang memiliki kemampuan untuk bersaing dengan negara lain. Sebagaimana kompetensi yang tercantum dalam Undang-Undang Republik Indonesia Nomor 20 Tahun 2003 pasal 3 tentang Sistem Pendidikan Nasional, yaitu beriman dan bertakwa kepada Tuhan Yang Maha Esa, berakhlak mulia, sehat, berilmu, cakap, kreatif, mandiri, dan menjadi warga negara yang demokratis, serta bertanggung jawab. Kompetensi tersebutlah yang dibebankan kepada setiap mata pelajarn di sekolah, termasuk Pendidikan Kewarganegaraan.

\section{Pendidikan}

Kewarganegaraan berusaha membentuk penerus bangsa yang memiliki pengetahuan dan karakter yang baik. Tentunya pengetahuan tersebut harus mengikuti perkembangan zaman, termasuk memahami masalah kewargannegaraan secara global. Adanya kegiatan tersebut akan membentuk generasi muda yang mampu bersaing di tingkat internasional dengan jiwa dan raga yang baik. Potensipotensi yang telah dikemukakan dapat dikembangkan kepada peserta didik melalui pembelajaran Pendidikan Kewarganegaraan di kelas.

Pada proses pembelajaran guru harus mampu mengajak peserta didik untuk mampu mengolah informasi dan melakukan kegiatan belajar tanpa bergantung pada orang lain. Kegiatan tersebut tentu akan melatih kemandirian peserta didik dalam melakukan kegiatan belajar. Selain itu guru juga harus mengajak peserta didik untuk menyelesaikan tugas yang diberikan dan menyelesaikan masalah yang sedang dihadapi. Kegiatan tersebut tentu akan melatih tanggung jawab peserta didik dalam melakukan kegiatan belajar. Adanya sikap mandiri dan tanggung jawab yang dilaksanakan atau dibiasakan di sekolah dan rumah diharapakan dapat membentuk generasi muda yang mandiri dan bertanggung jawab tanpa harus dipantau terlebih dahulu. Dengan kata lain, sikap mandiri dan tanggung jawab akan tertanam pada diri peserta didik dengan sendirinya.

Pada saat ini sikap mandiri dan tanggung jawab inilah yang kurang dimiliki oleh peserta didik. Berikut beberapa kasus yang menunjukkan sikap tidak mandiri yang terjadi di sekolah, yaitu kasus contek massal saat ujian nasional di SDN Gadel 2, Tandes, Surabaya (Joewono, 2011). Selain itu kasus saling contek ketika pelaksanaan ujian nasional juga terjadi pada salah satu Sekolah Menengah Atas (SMA) Negeri di Sungguminasa, Kabupaten Gowa, SulawesiSelatan (Haq, 2016).

Berikut beberapa kasus yang menunjukkan sikap tidak bertanggung jawab yang terjadi di sekolah, yaitu kasus bunuh diri yang dilakukan oleh pelajar SMA di Jembrana, Bali karena merasa malu dan kecewa terpergok berpacaran di toilet sekolah (Assifa, 2016). Selain itu kasus orang tua yang mengamuk di SMK Galuh Rahayu Dusun Bantar, Desa Sukaharja, Kecamatan Sindangkasih, Kabupaten Ciamis. Hal ini disebabkan karena putra dari orang tua tersebut dikeluarkan dari sekolah karena membolos (Hermansyah, 2015).

Berdasarkan kasus-kasus yang telah dikemukakan, diperlukan peran guru untuk mampu melatih peserta didik bersikap mandiri dan bertanggung jawab. Pembentukan dan penanaman sikap mandiri dan tanggung jawab pada peserta didik dapat dilakukan melalui metode yang diterapakan pada pembelajaran Pendidikan Kewarganegaraan. Salah satu metode pembelajaran tersebut adalah metode sosiodrama. Sebagaimana yang dikemukakan oleh Sudjana (2013: 90) bahwa metode sosiodrama merupakan metode pembelajaran yang mengajak peserta didik untuk bermain drama. Pada drama tersebut terdapat kegiatan peserta didik untuk memecahkan sebuah masalah. Oleh sebab itu, perlu adanya sikap mandiri 
dan tanggung jawab untuk mampu memecahkan bahkan menyelesaikan masalah tersebut.

Pertanyaan yang muncul adalah bagaimana cara menerapkan metode pembelajaran sosiodrama dalam pembelajaran Pendidikan Kewarganegaraan? Bagaimana cara membentuk sikap mandiri dan tanggung jawab melalui metode pembelajaran sosiodrama? Artikel ini akan mendeskripsikan tentang cara menerapkan metode pembelajaran sosiodrama dalam pembelajaran Pendidikan Kewarganegaraan dan cara membentuk sikap mandiri dan tanggung jawab melalui metode pembelajaran sosiodrama. Deskripsi ini diberikan agar guru dapat mengaplikasikan metode tersebut dengan baik di kelas sehingga sikap mandiri dan tanggung jawab pun dapat terbentuk dalam diri peserta didik.

\section{METODE}

\section{Jenis Penelitian}

Jenis penelitian ini merupakan penelitian kualitiatif deskriptif-kritis dengan menekankan pada library research. Library research sendiri merupakan penelitian yang menggunakan sumber perpustakaan untuk memperoleh data penelitiannya

\section{Target/Subjek Penelitian}

Target/subjek penelitian ini merupakan data-data yang berupa jurnal, buku, laporan penelitian yang terkait dengan topik sikap madniri, tangung jawab, sosio drama dan Pendidikan Kewarganegaraan.

\section{Prosedur}

Prosedur perlu dijabarkan menurut tipe penelitiannya. Bagaimana penelitian dilakukan dan data akan diperoleh, perlu diuraikan dalam bagian ini.

Untuk penelitian eksperimental, jenis rancangan (experimental design) yang digunakan sebaiknya dituliskan di bagian ini.

\section{Data, Intrumen, dan Teknik Pengumpulan Data}

Data pada penelitian ini menggunakan data data dari berbagai artikel ilmiah seperti laporan penelitian, buku, jurnal yang dikumpulkan dengan menggunakan teknik dokumentasi. Dimana peneleiti mendata kajian dari berbagai macam bahan-bahan ilmiah yang terkait dengan penelitian ini.

\section{Teknik Analisis Data}

Analisis data yang digunakan dalam penelitian ini yakni analisis isi. Analisis isi digunakan dengan cara membandingkan antara satu kajian dengan kajian yang lain dalam topik yang sesuai dengan artikel ini.

\section{HASIL DAN PEMBAHASAN}

\section{Konsep tentang Pendidikan Kewarganegaraan}

Pendidikan Kewarganegaraan merupakan mata pelajaran yang memuat materi tentang perkembangan suatu negara. Pendidikan Kewarganegaraan membahas tentang segala hal yang terjadi pada suatu negara dan berusaha membentuk generasi muda yang dapat mengikuti perkembangan zaman. Menurut Partnership for 21st Century Skills pada abad ke-21 dibutuhkan warga negara aktif, berpengetahuan politik, mampu menyelesaikan masalah, bermusyarah, berbagi pengetahuan antar individu, kreatif, dan inovatif (Jansen, 2011: 31). Kompetensi tersebut juga harus dikembangkan pada diri generasi muda melalui pembelajaran Pendidikan Kewarganegaraan. Itu berarti pembelajaran Pendidikan Kewarganegaraan harus mampu mengajak peserta didik untuk aktif, menuntut menyelesaikan masalah, bermusyarah, kreatif, dan inovatif

Berbeda dengan penjelasan yang diberikan oleh Audigier (Mirza, 2011: 31) yang mengungkapkan bahwa warga negara kritis merupakan kompetensi yang dibutuhkan oleh suatu negara. Hal ini disebabkan warga negara yang kritis adalah warga negara yang siap untuk memberikan 


\section{Copyright (c) 2017, Citizenship Jurnal Pancasila dan Kewarganegaraan}

Avaliable online at : http://e-journal.unipma.ac.id/index.php/citizenship

ISSN: $2302-433 \mathrm{X}$ (print) 2579-5740 (online)

kontribusi pada pembangunan negara. Warga negara yang kritis dianggap mampu untuk diajak bekerja sama dan menyelesaikan masalah yang sedang terjadi. Berdasarkan penjelasan tersebut menunjukkan bahwa warga negara kritis memiliki peran penting dalam pembangunan negara.

Sementara itu di Filipina, terdapat Philippine Center for Civic Education and Democracy (PCCED) sebagai program Pendidikan Kewarganegaraan tambahan yang mengajak peserta didik untuk memecahkan sebuah masalah. Pemecahan sebuah masalah dilakukan melalui diskusi. Melalui diskusi tersebut, peserta didik melakukan identifikasi masalah, selanjutnya penelitian berbasis masyarakat, pemeriksaan masalah yang terjadi di masyarakat, perumusan suatu kebijakan, dan melakukan simulasi. Melalui kegiatan tersebut dapat dilihat bahwa peserta didik mengembangkan nilai demokrasi (Pingul, 2015: 61). Menurut penjelasan yang telah diuraikan dapat dikatakan bahwa Pendidikan Kewarganegaraan di Filipina memberikan penekanan pada kemampuan peserta didik untuk mandiri memecahakan masalah dan bertanggung jawab menyelesaikan masalah tersebut.

Menurut Civic Ideals and Practices pembelajaran di kelas, khususnya dalam pembelajaran Pendidikan Kewarganegaraan harus menekankan pada praktik kewarganegaraan. Pembelajaran yang mengajak peserta didik untuk berpura-pura melaksanakan kegiatan pemilu ataupun melakukan musyawarah demi memperoleh demi memperoleh kesepakatan bersama akan mengajarkan tentang praktik kewarganegaraan pada peserta didik. Selain itu melalui kegiatan tersebut nilai demokrasi akan berkembang pada diri peserta didik. Kegiatan tersebut ditunjukkan pada pembelajaran yang mengajak peserta didik untuk bermain drama (Jansen, 2011: 32). Menurut penjelasan yang telah diuraikan dapat dikatakan bahwa Pendidikan
Kewarganegaraan harus mampu memberikan praktik kewarganegaraan melalui metode pembelajaran yang diterapkan di dalam kelas.

Materi Pendidikan Kewarganegaraan pun disesuaikan dengan masalah atau isu-isu global yang sedang dihadapi oleh suatu negara. Materi Pendidikan Kewarganegaraan di Yordania yang lebih menekankan pada perdamaian. Hal ini disebabkan karena perdamaian merupakan masalah penting yang terjadi di Yordania. Masalah kewarganegaraan lain yang sedang dihadapi Yordania, adalah keamanan dunia, keamanan nasional, demokrasi, stabilitas politik, Hak Asasi Manusia, toleransi, keadilan, kebebasan, moral, dan pembangunan (Jarrar \& Althubetat, 2013,: 83-84). Menurut penjelasan yang telah diuraikan dapat disimpulkan bahwa Pendidikan Kewarganegaan memuat materi tentang isu-isu global yang terjadi di suatu negara. Hal ini membuat penekanan materi Pendidikan Keawarganegaraan pada tiap negara berbeda.

Sementara itu menurut Reynolds (2012: 190) isu-isu global yang terdapat dalam materi Pendidikan Keawarganegaraan terfokus pada indentitas nasional, ekonomi, keamanan, dan pengetahuan kewarganegaraan internasional. Berdasarkan isu-isu global tersebut menunjukkan bahwa peran Pendidikan Keawarganegaraan untuk memberikan pengetahuan dan pemahaman kepada peserta didik tentang identitas nasional, ekonomi, keamanan, dan pengetahuan kewarganegaraan internasional. Adanya identitas nasional membuat suatu negara tidak mudah dipengaruhi oleh budaya negara lain. Adanya pengetahuan tentang ekonomi dan keamanan membuat suatu negara lebih mempererat persatuan agar tidak dijajah dan tidak tertinggal dari Negara lain. Adanya pengetahuan kewarganegaraan internasional membuat peserta didik paham keadaan yang sedang terjadi pada negara-negara lain. 


\section{Citizenship Jurnal Pancasila dan Kewarganegaraan Vol 3 No 1 Maret 2o17, hal 134-144 Avaliable online at : http://e-journal.unipma.ac.id/index.php/Citizenship ISSN: 2302-433X (print) 2579-5740 (online)}

Materi yang ada dalam Pendidikan Kewarganegaraan memuat tentang isu-isu global yang terjadi dalam suatu negara. Hal ini membuat Pendidikan Kewarganegaraan memiliki peran penting untuk berkontribusi dalam memberikan perubahan yang lebih baik pada negara tersebut. Sebagaimana penjelasan yang diberikan oleh Kennedy (2012: 122) bahwa peristiwa-peristiwa global yang terjadi memberikan sorotan pada peran Pendidikan Kewarganegaraan dalam mengubah dunia. Hal ini berarti bahwa Pendidikan Kewarganegaraan secara tidak langsung memberikan pengaruh pada perkembangan suatu negara.

Berdasarkan penjelasan mengenai Pendidikan Kewarganegaraan yang telah diungkapkan, penulis setuju dengan pernyataan yang diungkapkan oleh Jansen, Pingul, dan Reynolds bahwa Pendidikan Kewarganegaraan merupakan mata pelajaran yang memuat materi tentang isuisu global atau masalah kewarganegaraan. Oleh karena itu, pembelajaran Pendidikan Kewarganegaraan harus menekankan penyelesaian masalah dan praktik kewarganegaraan. Sehingga peserta didik sebagai penerus bangsa dapat berkontribusi dalam penyelesaian masalah kewarganegaraan baik secara nasional maupun internasional.

Sementara itu penulis kurang setuju dengan pendapat yang diungkapkan oleh Kennedy kemajuan sebuah negara tidak bisa dibebankan hanya kepada Pendidikan Kewarganegaraan. Hal ini disebabkan karena semua mata pelajaran atau ilmu yang diberikan di sekolah memiliki tujuan dan fungsi masing-masing. Oleh karena itu, semua mata pelajaran memberikan kontribusi untuk mengubah dunia. Peran tersebut tidak hanya dibebankan pada Pendidikan Kewarganegaraan.

\section{Jawab bagi Peserta Didik \\ Pentingnya Mandiri dan Tanggung}

Mandiri merupakan sikap yang tidak bergantung pada orang lain, berusaha menyelasaikan tugas dengan kemampuan sendiri. Peserta didik diharapakan memiliki sikap mandiri dalam mengerjakan tugas dan bertanggung jawab menyelesaikan tugas tersebut tepat waktu. Tentu sikap tersebut tidak hanya dilakukan di sekolah, tetapi dibiasakan pula dalam kehidupan seharihari.(Kementerian Pendidikan Nasional Badan Penelitian dan Pengembangan Pusat Kurikulum, 2010: 10).

Sementara itu penjelasan mengenai sikap mandiri juga diberikan oleh Drost (Fahradina, Ansari, \& Saiman, 2014: 56) yang mengungkapkan bahwa mandiri adalah kemampuan seseorang untuk menyelesaikan masalah yang sedang terjadi. Penyelesaian masalah tersebut dilakukan dengan usaha pribadi. Masalah juga dapat timbul ketika peserta didik melakukan kegiatan belajar. Peserta didik yang memiliki sikap mandiri akan berusaha mengatasi masalah dalam melakukan kegiatan belajar dengan usaha sendiri. Peserta didik tersebut menyadari bahwa hasil dari segala usaha yang telah dilakukan akan memperlihatkan kualitas dari diri pribadi dan menimbullkan suatu kepuasan tersendiri.

Sementara itu terdapat enam indikator yang terdapat dalam sikap mandiri sesuai penjelasan yang diberikan oleh Hidayati \& Listyani (Masriah, Sukestiyarno, \& Susilo, 2014: 158), yaitu (1) tidak bergantung pada orang lain dalam melaksanakan tugas yang diberikan; (2) memiliki rasa percaya diri dalam menunjukkan kemampuan diri; (3) disiplin dengan menyelesaikan tugas tepat waktu; (4) tanggung jawab dalam menyelesaikan tugas; (5) memiliki inisiatif tinggi untuk menyelesaikan masalah yang sedang dihadapi; dan (6) memiliki kontrol diri.

Sikap mandiri dapat berkembang ketika kegiatan belajar yang dilakukan menuntut peserta didik untuk bersikap mandiri. Sebagaimana pernyataan yang diungkapkan oleh Lamb (Ganda, Ngwakwe, \&Ambe, 2014: 76) bahwa sikap mandiri dapat muncul ketika guru mengajak peserta didik untuk mengontrol sendiri kegiatan 
belajar yang dilakukan. Selain itu guru juga mengajak peserta didik untuk mampu mengolah informasi secara pribadi. Peserta didik juga dituntut untuk mencari jalan keluar ketika mengalami hambatan dalam kegiatan pembelajaran.Selama proses pembelajaran berlangsung guru berusaha meminimalisir keinginan peserta didik untuk bergantung kepada teman lain ketika melakukan kegiatan belajar.

Sikap tanggung jawab dapat muncul ketika peserta didik telah memiliki sikap mandiri. Tanggung jawab peserta didik di sekolah adalah belajar. Peserta didik yang melakukan kegiatan belajar dengan kemampuan pribadi akan berusaha menyelesaikan tugas tersebut dengan baik. Menurut Ericson \& Ellett (1990: 3-4) peserta didik memiliki tanggung jawab pribadi dalam proses pembelajaran, yakni melakukan kegiatan belajar. Peserta didik memiliki tanggung jawab atas kelancaran pendidikan masing-masing. Menurut penjelasan yang telah diuraikan dapat dikatakan bahwa peseta didik memiliki tanggung jawab pribadi dalam mengikuti kegiatan pembelajaran di sekolah.

Sementara itu menurut Aisyah, Nusantoro, \& Kurniawan (2014: 45-48) terdapat beberapa indikator dalam sikap tanggung jawab, yaitu peserta didik memiliki komitmen pada tugas atau mengerjakan tugas yang diberikan dengan sungguh-sungguh. Peserta didik memiliki kedisiplinan dalam mengikuti kegiatan belajar mengajar. Hal ini dapat ditunjukkan dengan mengumpulkan tugas tepat waktu.Selain itu peserta didik patuh pada tata tertib dan sportif ketika melaksanakan tugas dari guru.

Sikap mandiri dan tanggung jawab peserta didik pun juga dipengaruhi oleh metode yang digunakan guru dalam pembelajaran di kelas. Metode yang berpusat pada peserta didik atau metode pembelajaran yang menekankan pada peran aktif peserta didik memberikan kesempatan untuk melakukan kegiatan belajar secara mandiri dan bertanggung jawab. Keberhasilan sebuah metode pembelajaran bergantung pada keaktifan peserta didik (Wright, 2011: 94). Menurut penjelasan yang telah diuraikan dapat dikatakan bahwa sikap mandiri dan tanggung jawab juga dipengaruhi oleh metode pembelajaran yang digunakan oleh guru dalam proses pembelajaran.

Sikap mandiri dan tanggung jawab sangat penting untuk dikembangkan pada diri peserta didik sebagai generasi muda bangsa. Sebuah negara harus mengikuti perkembangan zaman agar tidak tertinggal dari negara lain. Kemajuan tersebut terjadi pada segala aspek kehidupan, seperti aspek ekonomi, sosial, budaya, teknologi, dan pendidikan. Hal yang sangat disayangkan ketika kemajuan aspek kehidupan tersebut dapat mempengaruhi karakter peserta didik. Sebagaimana yang diungkapkan oleh Zahabioun, et al (2013: 196) bahwa identitas, ketergantungan, moralitas, budaya, etnis, agama, hak, dan tanggung jawab merupakan masalah kewarganegaraan global atau isu-isu global yang terjadi karena perubahan yang luas dan tak terduga dalam aspek ekonomi, politik, sosial, ilmiah, dan teknologi. Berdasarkan ungkapan tersebut sikap mandiri dan tanggung jawab sangat penting untuk dikembangkan pada diri generasi muda agar mampu menghadapi kemajuan zaman. Adanya perkembangan dua karakter tersebut pada penerus bangsa diharapkan mampu memberikan masa depan yang lebih baik pada sebuah negara.

Berdasarkan penjelasan mengenai pentingnya sikap mandiri dan tanggung jawab yang telah diungkapkan, penulis setuju dengan pernyataan yang diungkapkan oleh semua ahli bahwa peserta didik memiliki tanggung jawab pribadi berkaitan dengan kegiatan belajar yang dilakukan. Tanggung jawab tersebut dapat dilaksanakan ketika peserta didik memiliki sikap mandiri.Sikap mandiri dan tanggung jawab dapat dikembangkan pada diri peserta didik melalui metode pembelajaran yang 
mampu mendorong perkembangan karakter tersebut. Dengan kata lain metode pembelajaran harus mampu mendorong peserta didik untuk melakukan kegiatan belajar secara mandiri dan bertanggung jawab menyelesaikan tugas dengan baik.

Pembentukan Sikap Mandiri dan Tanggung Jawab melalui Metode Sosiodrama dalam Pembelajaran
Pendidikan Kewarganegaraan

Guru dapat membentuk sikap tanggung jawab dan mandiri pada diri peserta didik melalui metode pembelajaran yang diterapkan di dalam kelas, khususnya dalam pembelajaran Pendidikan Kewarganegaraan. Salah satu metode pembelajaran yang dapat diterapkan dalam pembelajaran Pendidikan Kewarganegaraan adalah metode sosiodrama. Sosiodrama merupakan sebuah metode pembelajaran yang menekankan pada pemberian pemecahan masalah yang terjadi di lingkungan sekitar. Hal ini sesuai dengan penjelasan yang diungkapkan oleh Sudjana (2013: 90) bahwa metode sosiodrama merupakan metode pembelajaran yang mengajak peserta didik untuk bermain drama. Pada drama tersebut terdapat kegiatan peserta didik untuk memecahkan sebuah masalah. Masalah tersebut dapat diselesaikan jika peserta didik memiliki sikap mandiri dan tanggung jawab

Penjelasan dari Sudjana sejalan dengan pernyataan yang diberikan oleh Graefe \& Vogel (Alaba, 2014: 1327) bahwa sosiodrama sebagai metode yang mengajak peserta didik untuk berani menghadapi sebuah masalah dan mampu memberikan pemecahan atas masalah yang dihadapi tidak hanya terjadi secara pribadi, tetapi juga terjadi di lingkuangan sekitar. Menurut penjelasan yang telah diuraikan dapat dikatakan bahwa metode sosiodrama mengajak peserta didik untuk bertanggung jawab memberikan solusi atas masalah yang ada dalam naskah drama yng telah dibuat.

Sementara itu menurut penjelasan yang diberikan oleh Ragnarsdottir \&
Dorkelsdottir (2012: 5-6) bahwa dalam sebuah permainan drama peserta didik dituntut secara aktif memahami materi yang diberikan oleh guru. Oleh karena itu, drama harus dimainkan sebaik mungkin sehingga pesan dapat tersampaikan kepada penonton dengan baik. Tentu drama yang dimainkan memuat tentang peristiwa atau sebuah masalah yang sering dihadapi oleh peserta didik.Hal ini disebabkan peserta didik lebih mudah memahami materi bukan hanya karena materi disampaikan dengan menggunakan metode pembelajaran yang menarik, tetapi juga karena materi tersebut disampaikan melalui bahasa yang seharihari didengar oleh peserta didik. Pada kegiatan tersebut peserta didik dituntut untuk mandiri memerankan dan menghayati sebuah karakter dan memahami materi yang berusaha disampaikan melalui drama yang dimainkan. Menurut penjelasan yang telah diuraikan dapat dikatakan bahwa metode sosiodrama dapat membuat peserta didik untuk lebih mudah memamahi materi yang disampaikan oleh guru.Materi tersebut berusaha disampaikan melalui metode pembelajaran yng menarik dan contoh peristiwa yang sering dihadapi peserta didik.

Menurut Sudjana (2013: 90-91) melalui metode pembelajaran sosiodrama, peserta didik dituntut untuk mampu menghargai dan menghayati perasaan orang lain. Selain itu melului metode sosiodrama pula, peserta didik diajak untuk mengembangkan rasa tanggung jawab pada diri pribadi. Langkah-langkah metode pembelajaran sosiodrama adalah:

1. Guru bersama peserta didik menentukan topik dan tujuan sosiodrama.

2. Guru menjelaskan situasi yang akan dimainkan peserta didik dalam drama.

3. Guru bersama peserta didik membentuk kelompok peranan, menyiapkan ruangan, naskah drama, dan alat-alat yang diperlukan.

4. Peserta didik bergabung dalam kelompok yang sudah disepakati dan 
menentukan para pemain atau pemegang peranan.

5. Guru memberi penjelasan kepada kelompok dan pemain peranan berkaitan dengan hal-hal yang harus dilakukan dalam drama.

6. Peserta didikmenanyakan hal-hal yang belum dipahami kepada guru.

7. Peserta didik bersiap untuk bermain drama.

8. Guru menetapkan waktu dalam permainandrama.

9. Peserta didik memainkan drama. Sementara itu guru mengawasi dan memberikan saran.

10. Peserta didik secara kelompok melakukan diskusi untuk memberikan pemecahan atas masalah berdasarkan drama yang telah dimainkan.

11. Guru bersama-sama peserta didik membuat kesimpulan.

Berdasarkan langkah-langkah metode sosiodrama yang telah diuraikan, dapat diidentifikasibahwa sikap mandiri ditunjukkan ketika peserta didik membuat naskah drama sesuai dengan tema yang disepakati. Selain itu mampu membagi pemegang peran dengan tepat. Peserta didik mampu memahami karakter yang akan dimainkan. Peserta didik mampu membentuk konsep materi secara pribadi berdasarkan naskah drama yang telah dibuat.Peserta didik mampu memainkan peran sesuai naskah drama.

Berdasarkan langkah-langkah metode sosiodrama yang telah diuraikan, dapat diidentifikasibahwa sikap tanggung jawab ditunjukkan ketika peserta didik bekerja dalam kelompok untuk membuat naskah drama. Ketika kerja kelompok tersebut, peserta didik bertanggung jawab untuk membuat naskah drama yang baik dan sesuai dengan tema yang telah disepakati.Pembagian peranpun harus dilakukan dengan adil.Selain itu sikap tanggung jawab juga dapat ditunjukkan ketika peserta didik bermain drama di depan kelas. Ketika bermain drama di depan kelas, peserta didik memiliki tanggung jawab memerankan tokoh sesuai naskah drama yang telah dibuat dengan baik agar pesan dapat tersampaikan. Sikap tanggung jawab juga dapat ditunjukkan ketika peserta didik selaku penonton harus memperhatikan dengan teliti drama yang sedang dimainkan oleh peserta didik lain di depan kelas. Kegiatan ini dilakukan agar peserta didik mengetahui dengan jelas kasus yang berusaha disampaikan sehingga dapat memberikan pemecahan masalah atas kasus tersebut.

Gagasan yang diberikan penulis adalah diadakannya pantauan tentang sikap mandiri dantanggung jawab pada diri peserta didik. Pantauan tersebut dilakukan oleh peserta didik (teman sebaya), guru, dan orang tua. Pertama, segala sikap yang mencerminkan dan tidak mencerminkan mandiridan tanggung jawab di sekolah pada seorang peserta didik akan dicatatat oleh teman sebaya pada kartu pantauan. Kartu tersebut akan diserahkan kepada guru. Kemudian dilakukan konfirmasi, bimbingan, serta penandatangan oleh guru. Kedua, segala sikap yang mencerminkan mandiri dan tanggung jawab dalam menghadapi dan menyelesaikan masalah dalam kehidupan sehari-hari oleh peserta didik akan dicatat dalam kartu pembiasaan. Pencatatan tersebut dilakukan oleh peserta didik itu sendiri ditandatangani oleh orang tua dan guru.Kegiatan tersebut dilakukan agar peserta didik sebagai generasi muda dapat menerapkan sikap mandiri dantanggung jawab tidak hanya di sekolah, tetapi juga dalam kehidupan sehari-hari.

Berdasarkan penjelasan mengenai metode sosiodrama, penulis setuju dengan pernyataan yang diungkapkan oleh semua ahli bahwa metode sosiodrama dapat membantu peserta didik dalam memahami materi yang diberikan oleh guru serta dapat mengembangkan sikap mandiridan tanggung jawab pada diri peserta didik. Hal ini disebabkan karena dalam metode sosiodrama dibutuhkan kemampuan pribadi 


\section{Citizenship Jurnal Pancasila dan Kewarganegaraan Vol 3 No 1 Maret 2o17, hal 134-144 \\ Avaliable online at : http://e-journal.unipma.ac.id/index.php/Citizenship ISSN: 2302-433X (print) 2579-5740 (online)}

dalam memahami materi yang berusaha disampaikan dalam drama, memerlukan kemampuan pribadi untuk memerankan karakter sesuai dengan naskah, tanggung jawab dalam kerjakelompok untuk menampilkan drama dengan baik, serta kerja kelompok untuk memberikan pemecahan atas masalah yang terkandung dalam cerita drama tersebut.

\section{SIMPULAN DAN SARAN}

\section{Simpulan}

Pendidikan

Kewarganegaraan merupakan mata pelajaran yang memuat materi tentang isu-isu global atau masalah kewarganegaraan. Oleh karena itu, pembelajaran Pendidikan Kewarganegaraan harus menekankan penyelesaian masalah dan praktik kewarganegaraan. Sehingga peserta didik sebagai penerus bangsa dapat berkontribusi dalam penyelesaian masalah kewarganegaraan baik secara nasional maupun internasional. Kemampuan untuk menyelesaikan masalah dapat terwujud ketika peserta didik memiliki sikap mandiri dan tanggung jawab.

Peserta didik memiliki tanggung jawab pribadi berkaitan dengan kegiatan belajar yang dilakukan. Tanggung jawab tersebut dapat dilaksanakan ketika peserta didik memiliki sikap mandiri.Sikap mandiri dan tanggung jawab dapat dikembangkan pada diri peserta didik melalui metode pembelajaran yang mampu mendorong perkembangan karakter tersebut. Dengan kata lain metode pembelajaran harus mampu mendorong peserta didik untuk melakukan kegiatan belajar secara mandiri dan bertanggung jawab menyelesaikan tugas dengan baik.

Metode sosiodrama dapat membantu peserta didik dalam memahami materi yang diberikan oleh guru serta dapat mengembangkan sikap mandiridan tanggung jawab pada diri peserta didik. Hal ini disebabkan karena dalam metode sosiodrama dibutuhkan kemampuan pribadi dalam memahami materi yang berusaha disampaikan dalam drama, memerlukan kemampuan pribadi untuk memerankan karakter sesuai dengan naskah, tanggung jawab dalam kerjakelompok untuk menampilkan drama dengan baik, serta kerja kelompok untuk memberikan pemecahan atas masalah yang terkandung dalam cerita drama tersebut.

\section{Saran}

Saran bagi dosen, dihapakan memberi pengetahuan dan latihan bagi mahasiswa sebagai calon guru untuk menerapkan metode pembelajaran yang inovatif agar peserta didik dapat berperan aktif dalam proses pembelajaran. Melalui latihan tersebut diharapkan dapat menciptakan calon guru yang kreatif dan pembelajaran pun menjadi menyenangkan. Saran bagi pengajar, diharapkan mampu menerapkan metode pembelajaran sosiodrama dengan baikdalam proses pembelajaran, khususnya pembelajaran Pendidikan Kewarganegaraan sehingga dapat menciptakan kualitas pembelajaran yang baik pula.

Penulis juga memberikan rekomendasi untuk perlu dilakukan pengkajian lanjutan, seperti memadukan metode pembelajaran sosiodrama dengan metode yang lain untuk memperkuat pengembangan sikap mandiri dan tanggung jawab pada generasi muda. Selain itu perlu diadakan penelitian untuk melihat keefektifan metode pembelajaran sosiodrama dalam mengembangkan sikap mandiri dan tanggung jawab pada peserta didik.

\section{DAFTAR PUSTAKA}

Aisyah, A'an, Nusantoro,Eko,\& Kurniawan, Kusnarto. (2014). Meningkatkan tanggung jawab belajar melalui penguasaan konten. Indonesian Journal of Guidance and Counseling, 3 (3), 4450.

Alaba, S. (2014). A study of the effectiveness of socio-drama learning package in promoting environmental knowledge and behaviour of secondary schools students in Osun State, Nigeria. 


\section{Copyright (c) 2017, Citizenship Jurnal Pancasila dan Kewarganegaraan}

Avaliable online at : http://e-journal.unipma.ac.id/index.php/citizenship

$$
\text { ISSN: } 2302-433 \mathrm{X} \text { (print) } 2579-5740 \text { (online) }
$$

Mediterranean Journal of Social Sciences, 5 (23), 1325-1330.

Assifa, F. (2 Mei 2016).Pelajar SMA Gantung Diri karena Kecewa Terpergok Pacaran di Toilet Sekolah.Diambil pada tanggal 25 Oktober 2016, dari http://regional.kompas.com/read/2016/0 5/02/06170831/Pelajar.SMA.Gantung.D iri.karena.Kecewa.Terpergok.Pacaran.di .Toilet.Sekolah

Ericson, D P dan Ellett, Frederick S. (1990). Taking student responsibility seriously. Educational Researcher, 19, 3-10.

Fahradina, Nova, Ansari, Bansu I., \& Saiman. (2014). Peningkatan kemampuan komunikasi matematis dan kemandirian belajar siswa smp dengan menggunakan model investigasi kelompok. Jurnal Didaktik Matematika, 1 (1), 54-64.

Ganda, Fortune, Ngwakwe, Collins C, \& Ambe, C M. (2014). Independent Research and a Deep Approach to Learning of Accounting Concepts: Students' View. Mediterranean Journal of Social Sciences, 5 (6), 75-89.

Haq, Abdul. (4 April 2016). Saling Contek Warnai Pelaksanaan UN di Gowa. Diambil pada tanggal 3 Agustus 2017, dari

http://regional.kompas.com/read/2016/0 4/04/13400071/Saling.Contek.Warnai.P elaksanaan.UN.di.Gowa

Hermansyah, D. (1 Desember 2015). Siswa Sering Bolos Dikeluarkan Sekolah, Orangtua Mengamuk. Diambil pada tanggal 25 Oktober 2016, dari http://daerah.sindonews.com/read/10659 02/21/siswa-sering-bolos-dikeluarkansekolah-orangtua-mengamuk1448959994

Jansen, B.A. (2011). Civic education and the learning behaviors of youth in the online environment: a call for reform. Journal of Social Studies Education Research, 2(2), 22-42.

Jarrar, Amani \& Althubetat, Qasem. (2013). Peace concepts in civic education curriculum: a jordanian university sample. Journal of Education and Practice, 4, 83-90.

Joewono, Benny N. (5 Juni 2011). Ada Gladi Resik Contek Massal di Gadel 2. Diambil pada tanggal 3 Agustus 2017, dari

http://edukasi.kompas.com/read/2011/0 6/05/20032985/Ada.Gladi.Resik.Nyonte k.Massal.di.UN.SD

Kementerian Pendidikan Nasional Badan Penelitian dan Pengembangan Pusat Kurikulum. (2010). Pengembangan pendidikan budaya dan karakter bangsa pedoman sekolah. Jakarta: Kementerian Pendidikan Nasional Badan Penelitian dan Pengembangan Pusat Kurikulum.

Kennedy, Kerry J. (2012). Global trends in civic and citizenship education: what are the lessons for nation states?. Education Sciences, 2, 121-135.

Masriah, S, \& Susilo, B.E.. (2014). Pengembangan karakter mandiri dan pemecahan masalah melalui model pembelajaran $\mathrm{mmp}$ pendekatan atong materi geometri. Unnes Journal of Mathematics Education, 2 (4), 157-163.

Mirza, N. M. (2011). Civic education and intercultural issues in Switzerland: Psychosocial dimensions of an education to "otherness". Journal of Social Science Education, 10 (4), 31-40.

Pingul, F.S. (2015). Measuring the impact of a supplemental civic education program on students' civic attitude and efficacy beliefs. Journal of Education and Training Studies, 3 (2), 61-69.

Ragnarsdottir, Asa Helga \& Dorkelsdottir, Rannveig Bjork. (2012). Creative learning through drama. International Journal of Drama in Education, 3 (1). 119.

Reynolds, Ruth. (2012). Civics and citizenship education in its global context:the complexity of global citizenship dialogues. Educ. Sci., 2, 190-192. 
Citizenship Jurnal Pancasila dan Kewarganegaraan Vol 3 No 1 Maret 2017, hal 134-144

Avaliable online at : http://e-journal.unipma.ac.id/index.php/Citizenship

ISSN: 2302-433X (print) 2579-5740 (online)

Sudjana, Nana. (2013). Dasar-dasar proses belajar mengajar. Bandung: Sinar Baru Algensindo.

Undang-Undang Republik Indonesia Nomor 20 Tahun 2003 tentang Sistem Pendidikan Nasional. Jakarta: Presiden RI.

Wright, G.B. (2011). Student-centered learning in higher education. International Journal of Teaching and Learning in Higher Education, 23 (3), 92-97.

Zahabioun, Shahla, et al. (2013). Global citizenship education and its implications for curriculum goals at the age of globalization. International Education Studies, 6 (1), 195-206. Paidi. (2008). Urgensi pengembangan kemampuan pemecahan masalah dan metakognitif siswa SMA melalui pembelajaran biologi. Prosiding, Seminar dan Musyawarah Nasional MIPA yang diselenggarakan oleh FMIPA UNY, tanggal $30 \mathrm{Mei}$ 2008. Yogyakarta: Universitas Negeri Yogyakarta. 